\title{
FAKTOR-FAKTOR YANG MEMPENGARUHI KUALITAS HIDUP TENAGA KERJA PENYANDANG DISABILITAS
}

\section{THE AFFECTING FACTORS FOR QUALITY OF LIFE OF DISABILITY WORKERS}

\author{
R. Wiliasih"1, D.F. Salsabila² \\ 1Program Studi Ekonomi Islam Fakultas Ekonomi dan Manajemen \\ Institut Pertanian Bogor, 16680 \\ 2Program Studi Ekonomi Islam Fakultas Ekonomi dan Manajemen \\ Institut Pertanian Bogor, 16680
}

\begin{abstract}
Islam and government explain that people with disability have the similar opportunity to normal people, including to get an occupation. Hence, this study aims to find the factors that affect quality of life on disability workers. This study used primary data which was based from interview to 64 disability workers who live in Bantul district and secondary data from related institutions. Quality of life was measured by ComQol- $\mathrm{A}_{5}$, whereas the factors were estimated by Ordinary Least Square (OLS). This study found that income, optimism, hope, social support, and religiosity affect positively to quality of life for workers with disability in Bantul district.
\end{abstract}

Keywords: Quality of Life, Workers with Disability, Equality

\begin{abstract}
ABSTRAK
Pandangan Islam dan kebijakan negara telah menyatakan bahwa penyandang disabilitas memiliki kesempatan yang setara, termasuk dalam mendapatkan kesempatan bekerja. Penelitian ini dilakukan untuk mengetahui faktor-faktor yang memengaruhi kualitas hidup tenaga kerja penyandang disabilitas. Penelitian dilakukan dengan cara mengumpulkan informasi menggunakan kuisioner yang diwawancarakan kepada 64 tenaga kerja penyandang disabilitas yang berada di Kabupaten Bantul maupun melalui pengumpulan data sekunder yang diperoleh dari institusi terkait. Kualitas hidup diukur dengan Comprehensive Quality of Life Scale for Adult (ComQol-A A $_{5}$, sedangkan faktor-faktor yang mempengaruhinya dianalisis menggunakan metode analisis regresi berganda. Penelitian menunjukkan bahwa pendapatan, optimisme, harapan, dukungan sosial, dan religiusitas berpengaruh positif secara parsial terhadap kualitas hidup tenaga kerja penyandang disabilitas.
\end{abstract}

Kata kunci: Kualitas Hidup, Tenaga Kerja Penyandang Disabilitas, Kesetaraan

Wiliasih, Ranti. 2017. Faktor-faktor yang Memengaruhi Kualitas Hidup Tenaga Kerja Penyandang Disabilitas. Jurnal Syarikah 3 (2): . 


\section{PENDAHULUAN}

Penyandang disabilitas merupakan kelompok masyarakat dengan keterbatasan yang dapat menghambat partisipasi dan peran serta dalam kehidupan bermasyarakat. Disabilitas bukan hanya kecacatan semata, namun merupakan fenomena multi dimensi yang terdiri dari fungsi tubuh, keterbatasan aktivitas, hambatan partisipasi dan faktor lingkungan (Kemenkes 2014:1).

Namun demikian, ditinjau dari faktor lingkungan, stigma mengenai disabilitas masih bertahan pada masyarakat. Sebagian masyarakat masih menganggap penyandang disabilitas sebagai golongan yang bergantung pada orang lain dan hanya memerlukan belas kasih. Pandangan ini mendiskriminasikan penyandang disabilitas sehingga tidak dapat memiliki kehidupan yang mandiri.

Berdasarkan sudut pandang Islam, golongan penyandang disabilitas tidak dapat didiskriminasikan hanya karena keterbatasan yang dimilikinya sebagaimana Hadis Riwayat ath-Thabrani, "Dari Abu Malik, Rasulullah bersabda Sesungguhnya Allah tidak melihat fisik, kedudukan, dan harta kalian. Akan tetapi, Dia hanya melihat hati kalian". Allah tidak pernah menyulitkan hambaNya dalam melaksanakan ibadah, tidak terkecuali ibadah yang berupa muamalah. Setiap manusia diberi kesempatan sama untuk berpartisipasi dalam seluruh aspek kehidupan termasuk kehidupan sosial ekonomi.

Negara juga telah berupaya dalam menghapus diskriminasi bagi penyandang disabilitas. Kementerian Sosial melakukan perubahan orientasi regulasi bagi penyandang disabilitas. Perubahan tersebut dapat dilihat melalui UndangUndang Republik Indonesia Nomor 8 Tahun 2016 tentang penyandang disabilitas sebagai pengganti UndangUndang Nomor 4 Tahun 1997 yang dianggap sudah tidak sesuai dengan paradigma penanganan penyandang disabilitas.

Pada Undang-Undang Republik Indonesia Nomor 8 Tahun 2016 Pasal 53 dituliskan bahwa lembaga pemerintahan, BUMN, maupun BUMD memiliki kuota minimal untuk mempekerjakan paling sedikit $2 \%$ tenaga kerja penyandang disabilitas. Adapun pada perusahaan swasta, Kuota minimal untuk memperkerjakan tenaga kerja penyandang disabilitas adalah 1\%. Kesempatan penyandang disabilitas untuk mendapatkan atau melakukan pekerjaan akan memberi kontribusi, baik pada tingkat individu penyandang disabilitas itu sendiri dalam bentuk kehidupan yang lebih produktif maupun pada tingkat nasional dalam bentuk peningkatan Produk Domestik Bruto (PDB).

Kesempatan untuk melibatkan tenaga kerja penyandang disabilitas menjadi hal yang penting untuk dilakukan seiring dengan peningkatan jumlah penyandang disabilitas di Indonesia. Data Survei Sosial Ekonomi Nasional (Susenas) menunjukkan bahwa penyandang disabilitas di Indonesia mengalami peningkatan dari tahun 2009 yakni dari angka 1.780 .200 jiwa menjadi 6.008.661 jiwa pada tahun 2012 (Kemenkes 2014:6).

Berdasarkan provinsi, data persentase penyandang disabilitas menunjukkan bahwa Bengkulu adalah provinsi dengan persentase tertinggi lalu diikuti oleh Provinsi DI Yogyakarta, Gorontalo, Bangka Belitung, dan Nusa Tenggara Barat (Kemenkes 2014:10). DI Yogyakarta memiliki persentase penyandang disabilitas tertinggi kedua di Indonesia berdasarkan data Susenas 2012. Namun demikian, upaya penerimaan bagi penyandang disabilitas di DI Yogyakarta cukup baik.

Ditinjau dari fasilitas umum DI Yogyakarta, peneliti Center for Universal Design and Diffabilities (CIUDD) UGM mengatakan bahwa aksesibilitas bagi penyandang disabilitas berjalan progresif walau belum signifikan dan terintegrasi 
(Syafi'ie 2014:276). Adapun dari sisi dukungan regulasi, Pemerintah mengeluarkan Peraturan Daerah (Perda) Nomor 4 tahun 2012 tentang perlindungan dan pemenuhan hak-hak penyandang disabilitas.

Pada awalnya. peraturan terkait penyetaraan kesempatan kerja bertujuan untuk meningkatkan kesejahteraan tingkat individual penyandang disabilitas. Namun demikian, keterlibatan penyandang disabilitas pada dunia kerja ternyata masih terbatas dan menghasilkan pendapatan yang kecil. Penilaian atas sejauh apa peraturan ketenagakerjaan penyandang disabilitas telah berdampak perlu dilakukan, salah satunya dengan mengukur kualitas hidup sebagai bentuk kesejahteraan individual tenaga kerja penyandang disabilitas (Liao et al. dalam Nofitri 2009:10).

\section{MATERI DAN METODE}

Penelitian ini dimulai dengan melakukan pengukuran kualitas hidup tenaga kerja penyandang disabilitas. Instrumen pengukuran kualitas hidup yang digunakan adalah ComQol-A5. Pengukuran kualitas hidup dengan instrumen ComQol$A_{5}$ dapat disesuaikan untuk penyandang disabilitas fisik hingga kognitif.

Setelah data skor kualitas hidup diperoleh, analisis yang dilakukan adalah menguji variabel bebas yang terpilih sebagai faktor-faktor yang mempengaruhi kualitas hidup sesuai dengan pendekatan teoritis dan empiris. Adapun variabel bebas yang digunakan dalam penelitian ini adalah usia, jenis kelamin, pendidikan formal, pendapatan, optimisme, harapan, dukungan sosial, dan religiusitas. Statistik inferensia yang digunakan dalam analisis penelitian ini adalah metode regresi linier berganda.

Populasi dalam penelitian ini adalah tenaga kerja penyandang disabilitas. Pemilihan responden dilakukan secara purposive sampling dengan kriteria berdomisili di Kabupaten Bantul dan sanggup melakukan wawancara. Jumlah responden yang terlibat dalam penelitian ini adalah 64 orang.

Data primer diperoleh melalui kuesioner yang diwawancarakan kepada responden. Responden yang dimaksud adalah tenaga kerja penyandang disabilitas di Kabupaten Bantul, DI Yogyakarta. Data primer terdiri dari karakteristik responden, skor kualitas hidup, dan skor dari faktor-faktor yang memengaruhi kualitas hidup. Data sekunder diperoleh dari berbagai sumber yang relevan, diantaranya buku referensi, laporan kegiatan, internet, serta informasi data dari instansi terkait yang berada di Kabupaten Bantul maupun Provinsi DI Yogyakarta.

\section{Operasional Variabel}

Kualitas hidup yang dimaksud dalam penelitian ini berdasarkan dengan definisi Cummins 1997 bahwa kualitas hidup merupakan penilaian kompleks yang tidak hanya diterjemahkan melalui pendekatan objektif namun juga pendekatan subjektif. Pengukuran kualitas objektif ke dalam tujuh indikator yaitu kondisi kekayaan material, kesehatan, waktu produktif, keakraban, keamanan, keterlibatan dalam lingkungan, dan emosi. Kualitas hidup subjektif dalam pengukuran yang direkomendasikan Cummins berupa tingkat kepuasan dan kepentingan terhadap tujuh indikator tersebut.

Optimisme dalam penelitian ini diartikan sesuai dengan teori Seligman 2006, bahwa pengukurannya didasarkan pada kondisi ketika individu menghadapi suatu permasalahan. Terdapat tiga dimensi krusial yang dapat menjadi indikator untuk pengukuran tingkat optimisme yaitu permanence atau perspektif terhadap jangka waktu keberadaan suatu masalah, pervasiveness atau perspektif terhadap penyebaran suatu masalah, dan personalization atau kepribadian individu ketika menghadapi suatu masalah. Individu yang optimis cenderung menganggap suatu masalah adalah hal yang sementara, tidak menyebar pada seluruh aspek hidupnya, dan tidak selalu menyalahkan dirinya sendiri atas masalah yang terjadi. 
Harapan yang digunakan dalam penelitian ini memiliki arti sesuai dengan teori Snyder et al. 2002 bahwa harapan merupakan refleksi dari kepercayaan individu untuk menemukan target, menentukan jalan untuk mencapainya, serta mempercayakan bahwa cara tersebut dapat dijalankan. Definisi tersebut telah melingkupi indikator dalam pengukuran tingkat harapan.

Dukungan sosial yang dimaksud dalam penelitian ini merujuk pada Lakey dan Cohen 2000, yang didasarkan pada perspektif individu terhadap kualitas dan keberadaan berbagai tipe dukungan yang diperolehnya baik berupa, appraisal (penilaian), belonging (kebersamaan), esteem (penghargaan), dan tangible (bukti nyata).

Adapun religiusitas yang dimaksud dalam penelitian ini adalah aspek yang dihayati individu dan telah menimbulkan suatu ketaatan yang kuat terhadap agama yang dianutnya. Pada agama Islam, bisa diartikan sebagai bentuk pendirian rukun Islam dan rukun iman.

\section{Instrumen Pengukuran Kualitas Hidup Comprehensive Quality of Life Scale (ComQol) $-\mathrm{A}_{\mathbf{5}}$}

ComQol-A $\mathrm{A}_{5}$ mendasarkan penilaian kualitas hidup pada aspek objektif dan subjektif yang dirumuskan pada tujuh indikator yaitu, kekayaan material, kesehatan, waktu produktif, keakraban, keamanan, keterlibatan dalam lingkungan, dan emosi. Alat penilaian ini menyediakan rangkaian pertanyaan dengan jawaban berbentuk skala Likert. Berdasarkan aspek yang dinilai, terdapat dua bagian pengukuran dalam ComQol-A $\mathrm{A}_{5}$ yaitu Objective Quality of Life (OQOL) dan Subjective Quality of Life (SQOL).

OQOL menekankan penilaian terhadap nilai-nilai material yang dimiliki. SQOL menekankan penilaian tingkat kepentingan dan kepuasan responden pada hal-hal yang dimilkinya seperti kekayaan material, kesehatan, waktu produktif, keakraban, keamanan, keterlibatan dalam lingkungan, dan emosi.
OQOL diukur melalui pertanyaan mengenai nilai-nilai material yang disajikan dalam skala likert dengan skala 1 hingga 5 . Semakin besar nilai OQOL berarti nilai material yang dimiliki oleh responden semakin tinggi. SQOL diukur dengan mengalikan nilai kepuasan dan kepentingan terhadap objek yang dimiliki.

\section{Teknik Analisis Data}

Metode yang digunakan untuk menganalisis faktor-faktor yang mempengaruhi kualitas hidup penyandang disabilitas adalah analisis regresi linier berganda. Alat analisis ini digunakan untuk mempelajari hubungan antara variabel bebas dan satu atau lebih variabel terikat.

Model regresi linier yang digunakan dengan metode Ordinary Least Square (OLS) yang mengharuskan untuk memenuhi asumsi Best Linear Unbias Estimator (BLUE) dalam melakukan pendugaan interval dan pengujian parameter regresi populasi. Hipotesis akan diuji menggunakan kriteria statistik dan ekonometrika untuk melihat nyata atau tidaknya suatu variabel bebas mempengaruhi variabel terikat. Agar hasil estimasi model regresi dapat dikatakan BLUE, maka model harus memenuhi syarat lolos dalam uji statistik dan terbebas dari pelanggaran uji asumsi klasik.

\section{Model Penelitian}

Model yang digunakan untuk menganalisis faktor-faktor yang memengaruhi kualitas hidup tenaga kerja penyandang disabilitas adalah sebagai berikut :

$\mathrm{QoL}=\beta_{0}+\beta_{1} \mathrm{AGE}+\beta_{2} \mathrm{GDR}+\beta_{3} \mathrm{EDU}+\beta_{4} \mathrm{LINC}+\beta_{5}$ $\mathrm{OPT}+\beta_{6} \mathrm{HOP}+\beta_{7} \mathrm{SUP}+\beta_{8} \mathrm{REL}+e$

Keterangan:

QoL : Kualitas hidup (skor)

Bo : Konstanta

$\beta 1, \beta n$ : Koefisien regresi

AGE : Usia (tahun)

GDR : Dummy jenis kelamin (1 = laki-laki, 0 = perempuan)

EDU : Pendidikan formal (tahun) 


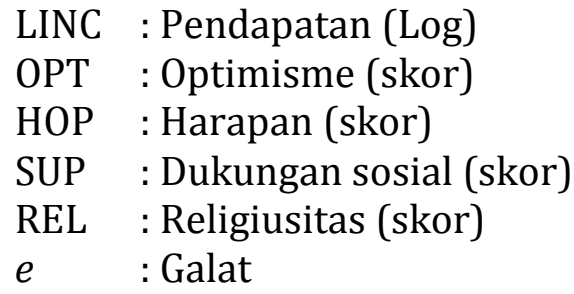

\section{Uji Asumsi Klasik}

Uji normalitas dimaksudkan untuk menguji apakah nilai residual yang telah distandarisasi pada model regresi berdistribusi normal atau tidak. Nilai residual dikatakan terdistribusi normal jika nilai residual terstandarisasi tersebut sebagian besar mendekati nilai rataratanya.

Mulitikolinieritas merupakan keadaan yang menunjukkan hubungan linier antara variabel bebas didalam persamaan regresi berganda. Hubungan linier antar variabel bebas dapat terjadi secara sempurna maupun tidak sempurna.

Heteroskedastisitas

merupakan keadaan ketika varian dari variabel galat (error) tidak konstan. Masalah heteroskedastisitas biasanya terjadi pada data cross-section. Permasalahan ini dapat menyebabkan estimator yang tidak memiliki varian minimum.

Autokorelasi merupakan keadaan ketika adanya korelasi antara variabel galat satu observasi dengan variabel galat observasi lain. Masalah autokorelasi biasanya terjadi pada data time series namun tidak menutup kemungkinan untuk terjadi pada data cross-section.

\section{Uji Statistik}

Koefisien determinasi $\left(\mathrm{R}^{2}\right)$ merupakan besarnya kontribusi variabel bebas terhadap variabel terikatnya. Nilai $\mathrm{R}^{2} \mathrm{yang}$ selalu terletak antara 0 dan 1 menunjukkan ukuran kesuaian model, bila nilai $\mathrm{R}^{2}=0$ maka variabel bebas sama sekali tidak dapat menjelaskan variabel terikat. Semakin tinggi nilai $\mathrm{R}^{2}$ berarti semakin baik kemampuan model dalam menjelaskan variasi perubahan variabel terikatnya.

Uji t dalam model regresi dilakukan untuk mengetahui secara parsial suatu variabel bebas berpengaruh secara signifikan atau tidak signifikan terhadap variabel terikat.

Uji $F$ digunakan untuk menguji pengaruh secara simultan variabel bebas terhadap variabel terikatnya. Jika variabel bebas memiliki pengaruh secara simultan terhadap variabel terikat, maka model persamaan regresi masuk dalam kriteria cocok atau fit.

\section{HASIL DAN PEMBAHASAN}

\section{Karakteristik Tenaga Kerja Penyandang Disabilitas}

Hasil penelitian menunjukkan bahwa $60,93 \%$ tenaga kerja penyandang disabilitas berjenis kelamin laki-laki, salah satu yang menjadi peyebabnya adalah karena kebanyakan dari golongan ini adalah kepala keluarga. Tingkat pendidikan formal terakhir yang paling banyak ditempuh responden adalah tingkat SMA yaitu sebanyak $51.51 \%$ dari total responden. Jenis disabilitas yang paling banyak dialami adalah tuna daksa atau kesulitan secara fisik namun tidak disertai kesulitan kognitif maupun indra pendengaran, pengelihatan, dan bicara. Jumlah responden dalam kategori tuna daksa adalah 85.94\%. Dominasi responden tuna daksa disebabkan karena kebanyakan responden merupakan korban gempa Yogyakarta tahun 2006. Adapun berdasarkan usia, responden didominasi oleh tenaga kerja penyandang disabilitas berusia 45 hingga 54 tahun, yaitu sebanyak $32.81 \%$ dari seluruh responden. Berdasarkan jenis pekerjaan yang dijalani, mayoritas tenaga kerja penyandang disabilitas berwirausaha mandiri dengan persentase $56.25 \%$, sedangkan yang bekerja sebagai karyawan berjumlah 35.94\%. Walau begitu, kebanyakan tenaga kerja penyandang disabilitas bekerja sebagai karyawan di sektor informal dengan upah yang tidak menentu. 


\section{Skor Kualitas Hidup Tenaga Kerja Penyandang Disabilitas}

Penilaian kualitas hidup tenaga kerja penyandang disabilitas di Kabupaten Bantul diukur berdasarkan ComQol-A5. Penilaian kualitas hidup dilakukan dengan pendekatan objektif dan subjektif dengan cara mengukur nilai, tingkat kepuasan, dan tingkat kepentingan terhadap tujuh indikator yang dimiliki responden yaitu kekayaan material, kondisi kesehatan, waktu produktif, keakraban, perasaan aman, keterlibatan dalam lingkungan, dan emosi.

Rentang nilai kualitas hidup ini berkisar antara 0 hingga 100. Kualitas hidup tenaga kerja penyandang disabilitas di Kabupaten Bantul memiliki nilai ratarata 71.18. yang diperoleh dari skor kualitas hidup objektif rata-rata bernilai 65.90 dan skor kualitas hidup subjektif rata-rata bernilai 76.46. Berdasarkan temuan ini, dapat diketahui bahwa pengaruh pengukuran subjektif berupa tingkat kepuasan dan tingkat kepentingan terhadap tujuh indikator memengaruhi kualitas hidup lebih besar dibandingkan pengukuran objektif. Berikut merupakan tabel yang menyajikan rangkuman dari keseluruhan hasil skor kualitas hidup penyandang disabilitas.

Tabel 1. Hasil Pengukuran Kualitas Hidup

\begin{tabular}{|l|c|}
\hline Skor Tertinggi & 91.25 \\
\hline Skor Terendah & 40.37 \\
\hline Rata-rata Skor & 71.18 \\
\hline $\begin{array}{l}\text { Jumlah responden dengan skor di } \\
\text { bawah rata-rata }\end{array}$ & $31(48.40 \%)$ \\
\hline $\begin{array}{l}\text { Jumlah responden dengan skor } \\
\text { diatas rata-rata }\end{array}$ & $33(51.60 \%)$ \\
\hline
\end{tabular}

\section{Kualitas Hidup Objektif}

Penilaian kualitas hidup objektif berdasarkan kekayaan material dilihat dari status kepemilikan rumah serta pendapatan bulanan yang diperoleh. Berdasarkan kepemilikan rumah, secara dominan responden penelitian telah menempati rumah milik pribadi. Kondisi kepemilikan rumah penyandang disabilitas secara umum digambarkan tabel 2 .
Tabel 2. Status Kepemilikan Rumah Responden

\begin{tabular}{|l|c|}
\hline \multicolumn{1}{|c|}{ Status Kepemilikan Rumah } & Persentase \\
\hline Milik Pribadi & $60.94 \%$ \\
\hline Rumah Sewaan & $6.25 \%$ \\
\hline Menumpang Orang Tua & $32.81 \%$ \\
\hline
\end{tabular}

Adapun berdasarkan pendapatan bulanan, secara dominan responden memiliki pendapatan diantara Rp 500,000 hingga $\mathrm{Rp} \quad 1,000,000$. Tingkat pendapatan disabilitas secara umum digambarkan tabel 3.

Tabel 3. Tingkat Pendapatan Responden

\begin{tabular}{|l|c|}
\hline \multicolumn{1}{|c|}{ Tingkat Pendapatan } & Persentase \\
\hline$<500,000$ & $12.5 \%$ \\
\hline $500,000-1,000,000$ & $45.31 \%$ \\
\hline $1,000,001-1,500,000$ & $14.06 \%$ \\
\hline $1,500,000-2,000,000$ & $20.31 \%$ \\
\hline$\geq 2,000,001$ & $7.82 \%$ \\
\hline
\end{tabular}

Penilaian kualitas hidup objektif berdasarkan kondisi kesehatan memperlihatkan bahwa 28 responden atau sekitar $43.75 \%$ dari seluruh responden yang diteliti tidak merasa terdapat gangguan kesehatan akibat kondisi disabilitas. Responden kategori ini didominasi oleh responden tuna daksa yang mengalami disabilitas sejak kecil seperti akibat penyakit polio atau kelainan genetika. Adapun 36 responden atau sekitar $56.25 \%$ dari seluruh responden yang diteliti mengalami gangguan kesehatan akibat kondisi disabilitas dalam tingkat keparahan yang berbeda. Responden kategori ini didominasi oleh korban gempa bumi pada tahun 2006 yang menjadi pengguna kursi roda dan mengalami Paraplegia. Paraplegia adalah hilangnya kemampuan menggerakan anggota tubuh bagian bawah akibat gangguan sistem saraf pada otot-otot yang mengontrol bagian tersebut. Salah satu responden bahkan harus terus mengikat kakinya akibat kejang kaki berlebihan yang dapat muncul sewaktu-waktu. Selain itu, responden pengguna kursi roda yang mengalami Paraplegia juga sering mengalami nyeri bahkan beberapa mengaku bahwa nyeri tersebut dapat mengganggu jam istirahat malam mereka. 
Responden pengguna kursi roda juga terancam untuk mendapatkan penyakit Ulkus Dekubitus yaitu penyakit yang diakibatkan oleh tekanan yang terus dibebankan pada tubuh bagian bawah, seperti akibat duduk terlalu lama pada kursi roda. Berdasarkan penjelasan salah satu responden yang merupakan anggota Handicap International, penyakit ini sangat fatal dan menyebabkan beberapa tetangganya yang merupakan korban gempa pengguna kursi roda meninggal dunia. Kondisi kesehatan penyandang disabilitas secara umum digambarkan tabel 4.

Tabel 4. Frekuensi Gangguan Kesehatan

\begin{tabular}{|l|c|}
\hline $\begin{array}{c}\text { Frekuensi Gangguan Kesehatan } \\
\text { Akibat Kondisi Disabilitas }\end{array}$ & Persentase \\
\hline Tidak Pernah & $43.75 \%$ \\
\hline Jarang & $40.62 \%$ \\
\hline Sering dan Tidak Parah & $7.81 \%$ \\
\hline Sering dan Cukup Parah & $6.25 \%$ \\
\hline Sering dan Sangat Parah & $1.57 \%$ \\
\hline
\end{tabular}

Kualitas hidup objektif berdasarkan waktu produktif menekankan penilaian pada jumlah jam yang digunakan responden tiap minggunya untuk kegiatan bekerja, pendidikan atau pelatihan, dan pekerjaan rumah. Kebanyakan responden menghabiskan waktu selama 31 hingga 40 jam lebih per minggu untuk bekerja, dengan persentase $79.69 \%$ atau sejumlah 51 orang dari seluruh responden. Tabel 5 akan menggambarkan jam bekerja yang dihabiskan seluruh responden tiap minggunya.

Tabel 5. Jumlah Jam per Minggu yang Digunakan untuk Bekerja

\begin{tabular}{|l|c|}
\hline $\begin{array}{c}\text { Jumlah Jam per Minggu yang } \\
\text { Digunakan untuk Bekerja }\end{array}$ & Persentase \\
\hline 0 jam & $0 \%$ \\
\hline $1-10$ jam & $1.57 \%$ \\
\hline $11-20$ jam & $4.68 \%$ \\
\hline $21-50$ jam & $14.06 \%$ \\
\hline $31-40+$ jam & $79.69 \%$ \\
\hline
\end{tabular}

Berdasarkan waktu yang digunakan untuk pendidikan atau pelatihan, kebanyakan responden tidak menjalani pelatihan rutin. Total responden untuk kategori ini adalah 56 orang atau sekitar
$87.50 \%$ dari seluruh responden. Hal ini patut menjadi perhatian karena walaupun tidak terdapat pelatihan rutin, responden mengaku memiliki ketertarikan untuk mengikuti kegiatan di luar rumah seperti pelatihan. Pelatihan biasanya hanya dilakukan beberapa kali dalam setahun oleh Dinas Sosial. Minat responden untuk mengikuti pelatihan secara rutin belum dapat diakomodir dengan baik. Tabel 6 akan menggambarkan jumlah jam yang digunakan seluruh responden untuk kegiatan pendidikan atau pelatihan.

Tabel 6. Jumlah Jam per Minggu yang Digunakan untuk Pendidikan/ Pelatihan

\begin{tabular}{|l|c|}
\hline $\begin{array}{c}\text { Jumlah Jam per Minggu yang } \\
\text { digunakan untuk } \\
\text { Pendidikan/Pelatihan }\end{array}$ & Persentase \\
\hline 0 jam & $87.50 \%$ \\
\hline $1-10$ jam & $6.25 \%$ \\
\hline $11-20$ jam & $4.68 \%$ \\
\hline $21-50$ jam & $15.62 \%$ \\
\hline $31-40+$ jam & $0 \%$ \\
\hline
\end{tabular}

Berdasarkan waktu yang digunakan untuk melakukan pekerjaan rumah, kebanyakan responden menghabiskan sekitar 31 hingga 40 jam lebih per minggu. Total responden yang menghabiskan waktu sekitar 31 hingga 40 jam lebih per minggu untuk pekerjaan rumah adalah 19 orang atau sekitar 29.69\% dari seluruh responden. Tabel 7 akan menggambarkan jumlah jam yang digunakan seluruh responden untuk melakukan pekerjaan rumah tiap minggunya.

Tabel 7. Jumlah Jam per Minggu yang Digunakan untuk Pekerjaan Rumah

\begin{tabular}{|l|c|}
\hline $\begin{array}{c}\text { Jumlah Jam per Minggu yang } \\
\text { digunakan untuk Pekerjaan } \\
\text { Rumah }\end{array}$ & Persentase \\
\hline 0 jam & $18.75 \%$ \\
\hline $1-10$ jam & $18.75 \%$ \\
\hline $11-20$ jam & $14.06 \%$ \\
\hline $21-50$ jam & $18.75 \%$ \\
\hline $31-40+$ jam & $29.69 \%$ \\
\hline
\end{tabular}

Penilaian kualitas hidup objektif berdasarkan keakraban memperlihatkan kondisi kepedulian masyarakat terhadap tenaga kerja penyandang disabilitas. Berdasarkan indikator keakraban, 
diketahui bahwa 30 orang atau sekitar $46.87 \%$ responden mengaku masyarakat disekitarnya hampir selalu peduli terhadap penyandang disabilitas. Hal ini didukung dengan fakta di lapangan bahwa ikatan sosial yang tinggi diantara masyarakat pedesaan masih sangat terasa. Ikatan silaturahmi masih terasa erat pada masyarakat desa di Kabupaten Bantul. Tabel 8 akan menunjukkan tingkat keakraban seluruh responden.

Tabel 8. Frekuensi Kepedulian

Masyarakat terhadap Responden

\begin{tabular}{|l|c|}
\hline $\begin{array}{c}\text { Frekuensi Kepedulian } \\
\text { Masyarakat terhadap Responden }\end{array}$ & Persentase \\
\hline Hampir Tidak Pernah & $0 \%$ \\
\hline Tidak Sering & $31.25 \%$ \\
\hline Kadang-kadang & $15.62 \%$ \\
\hline Sering & $34.37 \%$ \\
\hline Hampir Selalu & $18.76 \%$ \\
\hline
\end{tabular}

$\begin{array}{rrr}\text { Penilaian } & \begin{array}{r}\text { kualitas hidup objektif } \\ \text { berdasarkan }\end{array} & \text { perasaan }\end{array}$ memperlihatkan kecenderungan responden terhadap perasaan cemas. Perasaan cemas yang dimaksud meliputi berbagai hal tanpa batasan pada kasus tertentu. Berdasarkan indikator perasaan aman diketahui bahwa 27 responden atau sekitar $42.19 \%$ merasa hampir tidak pernah mengalami kecemasan berlebihan, walau begitu 7 responden atau sekitar $10.94 \%$ mengaku masih sering mengalami kecemasan akibat trauma terhadap getaran-getaran seperti halnya gempa bumi. Tabel 9 menunjukkan indikator keamanan responden berdasarkan kecenderungan perasaan cemas.

Tabel 9. Frekuensi Kecenderungan

Responden terhadap Rasa Cemas

\begin{tabular}{|l|c|}
\hline $\begin{array}{c}\text { Frekuensi Kecenderungan } \\
\text { Responden terhadap Rasa Cemas }\end{array}$ & Persentase \\
\hline Hampir Tidak Pernah & $42.19 \%$ \\
\hline Tidak Sering & $23.44 \%$ \\
\hline Kadang-kadang & $23.44 \%$ \\
\hline Sering & $10.93 \%$ \\
\hline Hampir Selalu & $0 \%$ \\
\hline
\end{tabular}

Penilaian kualitas hidup objektif berdasarkan keterlibatan pada lingkungan memperlihatkan peran penyandang disabilitas terhadap kegiatan masyarakat.
Berdasarkan indikator tersebut, diketahui bahwa 30 responden atau sekitar $46.87 \%$ diantara seluruh responden hampir selalu dimintai bantuan atau pendapat oleh masyarakat di luar rumah. Bahkan beberapa responden memegang tanggung jawab dalam lingkungan tempat tinggalnya, seperti menjadi penjaga masjid, penanggung jawab karang taruna, dan lainnya. Adapun, secara keseluruhan tidak ada satu pun responden yang mengaku tak pernah dilibatkan oleh masyarakat. Tabel 10 menunjukkan tingkat keterlibatan seluruh responden pada lingkungan.

Tabel 10. Frekuensi Keterlibatan

Responden terhadap Kegiatan Masyarakat

\begin{tabular}{|l|c|}
\hline $\begin{array}{c}\text { Frekuensi Keterlibatan } \\
\text { Responden terhadap Kegiatan } \\
\text { Masyarakat }\end{array}$ & Persentase \\
\hline Hampir Tidak Pernah & $0 \%$ \\
\hline Tidak Sering & $10.94 \%$ \\
\hline Kadang-kadang & $10.94 \%$ \\
\hline Sering & $31.25 \%$ \\
\hline Hampir Selalu & $46.87 \%$ \\
\hline
\end{tabular}

Penilaian kualitas hidup objektif berdasarkan indikator emosi menunjukkan kecenderungan responden dalam menahan diri terhadap hal-hal yang diinginkan. Berdasarkan indikator tersebut, diketahui bahwa kebanyakan responden cukup baik dalam mengelola emosinya. Total responden yang hampir selalu mampu menahan emosi diri adalah 22 orang atau sekitar $34.37 \%$ dari keseluruhan responden. Adapun 21 orang atau sekitar $32.81 \%$ responden mengaku cukup sering menahan emosi diri. Tingkat pengelolaan emosi juga terkait dengan kesabaran responden ketika muncul rasa sakit akibat disabilitasnya. Tabel 11 menunjukkan tingkat pengelolaan emosi responden. 
Tabel 11. Frekuensi Responden dalam Menahan Diri terhadap Hal-hal yang Diinginkan

\begin{tabular}{|l|c|}
\hline $\begin{array}{c}\text { Frekuensi Responden dalam } \\
\text { Menahan Diri terhadap Hal-hal } \\
\text { yang Diinginkan }\end{array}$ & Persentase \\
\hline \multicolumn{1}{|c|}{ Hampir Tidak Pernah } & $0 \%$ \\
\hline Tidak Sering & $21.88 \%$ \\
\hline Kadang-kadang & $10.94 \%$ \\
\hline Sering & $32.81 \%$ \\
\hline Hampir Selalu & $34.37 \%$ \\
\hline
\end{tabular}

Kualitas Hidup Subjektif

Penilaian kualitas hidup subjektif dilakukan dengan cara menilai persepsi tingkat kepentingan dan tingkat kepuasan responden terhadap aspek material yang telah dinilai pada kualitas hidup objektif. Secara keseluruhan, aspek material yang dinilai paling penting bagi responden adalah kondisi kesehatan dan hubungan dengan keluarga maupun teman. Hampir seluruh aspek material mendapatkan nilai dominan pada skala 'sangat penting'. Namun terdapat satu penilaian aspek material yang mendapat nilai dominan pada skala 'penting', yaitu kekayaan material. Tabel 12 menunjukkan aspek material berdasarkan penilaian tingkat kepentingan dominan.

Tabel 12. Skala Penilaian Subjektif Dominan Berdasarkan Tingkat Kepentingan

\begin{tabular}{|l|c|c|}
\hline \multicolumn{1}{|c|}{ Aspek Material } & $\begin{array}{c}\text { Skala Penilaian } \\
\text { Dominan }\end{array}$ & Persentase \\
\hline $\begin{array}{l}\text { Kekayaan } \\
\text { material }\end{array}$ & Penting & $53.12 \%$ \\
\hline $\begin{array}{l}\text { Kondisi } \\
\text { kesehatan }\end{array}$ & Sangat penting & $93.75 \%$ \\
\hline Waktu produktif & Sangat penting & $65.62 \%$ \\
\hline Keakraban & Sangat penting & $85.94 \%$ \\
\hline Perasaan aman & Sangat penting & $51.56 \%$ \\
\hline $\begin{array}{l}\text { Keterlibatan } \\
\text { pada Lingkungan }\end{array}$ & Sangat penting & $54.69 \%$ \\
\hline Emosi & Sangat penting & $53.12 \%$ \\
\hline
\end{tabular}

Aspek material yang dinilai 'paling memuaskan' bagi mayoritas responden adalah hubungan dengan keluarga maupun teman dan aktivitas bersama orang-orang di luar rumah. Adapun untuk penilaian aspek material yang didominasi pada skala 'puas' adalah kekayaan material, kondisi kesehatan, dan pengalaman hidup. Tabel 13 menunjukkan aspek material berdasarkan tingkat kepuasan dominan.

Tabel 13. Skala Penilaian Subjektif Dominan Berdasarkan Tingkat Kepentingan

\begin{tabular}{|l|c|c|}
\hline \multicolumn{1}{|c|}{ Aspek Material } & $\begin{array}{c}\text { Skala Penilaian } \\
\text { Dominan }\end{array}$ & Persentase \\
\hline $\begin{array}{l}\text { Kekayaan } \\
\text { material }\end{array}$ & Puas & $39.06 \%$ \\
\hline $\begin{array}{l}\text { Kondisi } \\
\text { kesehatan }\end{array}$ & Puas & $46.87 \%$ \\
\hline Waktu produktif & Puas & $42.19 \%$ \\
\hline Keakraban & Sangat puas & $37.50 \%$ \\
\hline Perasaan aman & Sangat puas & $48.43 \%$ \\
\hline $\begin{array}{l}\text { Keterlibatan pada } \\
\text { Lingkungan }\end{array}$ & Sangat puas & $50.00 \%$ \\
\hline Emosi & \multicolumn{2}{|l}{} \\
\hline
\end{tabular}

\section{Faktor-faktor yang Mempengaruhi Kualitas Hidup Tenaga Kerja Penyandang Disabilitas di Kabupaten Bantul, DI Yogyakarta}

Penelitian untuk mengetahui faktorfaktor kualitas hidup tenaga kerja penyandang disabilitas menggunakan metode analisis regresi linier berganda yang diestimasi menggunakan aplikasi Eviews 8. Variabel terikat dalam penelitian ini adalah nilai kualitas hidup yang diperoleh oleh setiap responden sedangkan variabel bebas yang diduga memengaruhi kualitas hidup tenaga kerja penyandang disabilitas adalah usia, jenis kelamin, tingkat pendidikan formal, pendapatan, optimisme, harapan, dukungan sosial, dan religiusitas. Sebelum memperoleh nilai dari uji statistik dilakukan uji asumsi terlebih dahulu untuk melihat normalitas sebaran data serta mendeteksi keberadaan heteroskedastisitas, autokorelasi, dan mutikolinieritas. Uji asumsi dilakukan untuk memastikan bahwa penelitian memiliki model yang Best Linear Unbiased Estimator (BLUE). Berikut merupakan hasil dari uji asumsi yang telah dilakukan.

\section{Uji Asumsi Klasik}

Uji normalitas dilakukan untuk melihat apakah model telah memenuhi asumsi 
normalitas. Berdasarkan uji normalitas, diperoleh nilai probabilitas 0.073567 . Nilai tersebut lebih besar dari taraf nyata $(\alpha=$ $5 \%$ ), sehingga dapat diketahui bahwa galat pada model terdistribusi normal dalam model dan memenuhi asumsi normalitas.

Uji heteroskedatisitas dapat dilakukan dengan menggunakan Uji White. Berdasarkan perhitungan Uji White terhadap data penelitian yang telah dilakukan, diperoleh probabilitas $\mathrm{F}$ senilai 0.9866. Nilai tersebut diatas taraf nyata $(\alpha=$ 5\%). Hasil tersebut menujukkan bahwa Hipotesis null yang menyatakan tidak adanya heteroskedastisitas dapat diterima. Hal ini secara otomatis menunjukkan bahwa tidak terdeteksi keberadaan heteroskedastisitas pada model penelitian.

Uji autokorelasi dapat dilakukan dengan Breusch-GodfreySerial Correlation LM Test. Berdasarkan hasil uji, diperoleh probabilitas F senilai 0.4130 . Nilai tersebut lebih besar dari taraf nyata $(\alpha=5 \%)$. Hasil tersebut menujukkan bahwa Hipotesis null yang menyatakan tidak adanya autokorelasi dapat diterima. Hal ini secara otomatis menunjukkan bahwa tidak terdeteksi keberadaan autokorelasi pada model penelitian.

Uji multikolinieritas dapat dilakukan dengan cara melihat nilai Centered Variance Inflating Factor (VIF) atau dengan melihat koefisien korelasi antar tiap variabel bebas. Jika terdapat nilai Centered VIF yang melebihi angka 10, maka model terdeteksi mengalami multikolinieritas. Berdasarkan uji VIF, model pada penelitian ini memiliki nilai Centered VIF di bawah 10. Sehingga model dalam penelitian ini tidak terdeteksi mengalami multikolinieritas. Adapun berdasarkan koefisien korelasi yang didapatkan, nilai yang diperoleh tidak ada yang melampaui 0.8. Sehingga dapat dipastikan bahwa model terbebas dari multikolinieritas baik berdasarkan uji VIF maupun Koefisien korelasi.

Setelah melakukan uji asumsi dan diketahui bahwa model tergolong BLUE, maka uji statistik dapat dilakukan. Uji statistik dilakukan melalui uji koefisien determinasi $\left(\mathrm{R}^{2}\right)$, Uji t, dan Uji F.

\section{Uji Statistik}

Nilai $\mathrm{R}^{2}$ yang diperoleh dari hasil estimasi pada model penelitian adalah 0.605775. Berdasarkan hasil tersebut dapat diketahui bahwa sekitar $60.57 \%$ keragaman kualitas hidup tenaga kerja penyandang disabilitas di Kabupaten Bantul dapat dijelaskan oleh delapan variabel bebas dalam model yaitu usia, jenis kelamin, tingkat pendidikan formal, pendapatan, optimisme, harapan, dukungan sosial, dan religiusitas. Sisanya, yaitu sebesar 39.43\% keragaman kualitas hidup tenaga kerja penyandang disabilitas dijelaskan oleh variabel lain di luar model.

Berdasarkan uji t, diketahui bahwa lima dari delapan variabel bebas memiliki nilai probabilitas dibawah taraf nyata ( $\alpha=0.05$ atau 0.10 ). Pendapatan, optimisme, dukungan sosial, dan religiusitas berpengaruh signifikan secara parsial ketika $\alpha$ bernilai 0.05 , sedangkan harapan berpengaruh ketika $\alpha$ bernilai 0.10 . Walau begitu, tiga variabel tidak berpengaruh parsial secara signifikan karena memiliki nilai probabilitas di atas taraf nyata baik ketika $\alpha$ bernilai 0.05 maupun 0.10 .

Hasil estimasi menunjukkan probabilitis $\mathrm{F}$ yang diperoleh dalam model penelitian ini adalah 0.0000. Nilai probabilitas $\mathrm{F}$ tersebut di bawah taraf nyata $(\alpha=0.01)$. Berdasarkan nilai tersebut, diketahui bahwa usia, jenis kelamin, tingkat pendidikan formal, pendapatan, optimisme, harapan, dukungan sosial, dan religiusitas berpengaruh secara simultan terhadap kualitas hidup tenaga kerja penyandang disabilitas.

\section{Hasil Estimasi Analisis Regresi Berganda}

Faktor-faktor yang memengaruhi kualitas hidup tenaga kerja penyandang disabilitas di Kabupaten Bantul dapat diketahui dengan cara melihat hasil estimasi analisis regresi berganda sebagai berikut. 


\begin{tabular}{|c|c|c|c|c|}
\hline Variabel & \multicolumn{2}{|c|}{ Koef. } & \multicolumn{2}{|c|}{ Prob. } \\
\hline AGE & \multicolumn{2}{|c|}{0.169777} & \multicolumn{2}{|c|}{0.1171} \\
\hline EDU & \multicolumn{2}{|c|}{0.234853} & \multicolumn{2}{|c|}{0.4623} \\
\hline GDR & \multicolumn{2}{|c|}{-1.369784} & \multicolumn{2}{|c|}{0.4685} \\
\hline $\mathrm{HOP}$ & \multicolumn{2}{|c|}{0.686231} & \multicolumn{2}{|c|}{$0.0571^{* *}$} \\
\hline LOGINC & \multicolumn{2}{|c|}{8.738667} & \multicolumn{2}{|c|}{$0.0078^{*}$} \\
\hline OPT & \multicolumn{2}{|c|}{0.938307} & \multicolumn{2}{|c|}{$0.0175^{*}$} \\
\hline REL & \multicolumn{2}{|c|}{0.616550} & \multirow{2}{*}{\multicolumn{2}{|c|}{$0.0407^{*}$}} \\
\hline SUP & \multirow{2}{*}{\multicolumn{2}{|c|}{$\begin{array}{r}0.626157 \\
-70.48086\end{array}$}} & \multirow{2}{*}{\multicolumn{2}{|c|}{$\frac{0.0197^{*}}{0.0012^{*}}$}} \\
\hline $\mathrm{C}$ & & & & \\
\hline R-squared & 0.605775 & \multicolumn{2}{|c|}{$\begin{array}{l}\text { Prob } \\
\text { (F-statistic) }\end{array}$} & $\begin{array}{c}0.00000 \\
0\end{array}$ \\
\hline $\begin{array}{l}\text { Adjusted } \\
\text { R-squared }\end{array}$ & 0.548433 & \multicolumn{2}{|c|}{$\begin{array}{l}\text { Durbin- } \\
\text { Watson stat }\end{array}$} & $\begin{array}{c}1.71726 \\
9 \\
\end{array}$ \\
\hline
\end{tabular}

Variabel pendapatan berpengaruh positif terhadap kualitas hidup tenaga kerja penyandang disabilitas dengan koefisien sebesar 8.738. Hal ini menunjukkan bahwa setiap terjadi kenaikan pendapatan sebesar 1\% maka kualitas hidup tenaga kerja penyadang disabilitas akan naik sebesar 8.738\%. Namun demikian, walau memiliki pengaruh yang besar tingkat pendapatan yang diperoleh oleh mayoritas tenaga kerja penyandang disabilitas di Kabupaten Bantul masih tergolong rendah. Upah Minimum Regional (UMR) yang ditetapkan Pemerintah Kabupaten Bantul adalah Rp 1,404,760 sedangkan kebanyakan tenaga kerja penyandang disabilitas di Kabupaten Bantul mendapat pendapatan di bawah UMR yaitu diantara Rp 500,000 hingga Rp 1,000,000. Hal ini salah satunya diakibatkan oleh jenis pekerjaan mayoritas tenaga kerja penyandang disabilitas yang berada di sektor informal dengan tingkat upah yang rendah dan tidak pasti.

Variabel optimisme berpengaruh positif terhadap kualitas hidup tenaga kerja penyandang disabilitas dengan koefisien sebesar 0.938. Hal ini menunjukkan bahwa setiap terjadi peningkatan optimisme sebesar 1\% maka kualitas hidup tenaga kerja penyandang disabilitas akan naik sebesar $0.938 \%$. Hasil ini sesuai dengan fakta di lapangan, bahwa masyarakat Bantul menjalani hidupnya tanpa terlalu lama terpuruk dari kondisi disabilitasnya. Responden fokus untuk beraktivitas atau melakukan kegiatan produktif sehariharinya dengan bekerja, bergaul dengan masyarakat sekitar, bahkan terus latihan olahraga dan mengikuti Paralimpiade yaitu olimpiade olahraga tingkat nasional untuk penyandang disabilitas. Beberapa dari responden penelitian adalah atlet yang bahkan menjuarai Paralimpiade tingkat nasional tersebut.

Variabel harapan berpengaruh positif terhadap kualitas hidup tenaga kerja penyandang disabilitas dengan koefisien sebesar 0.686. Hal ini menunjukkan bahwa setiap terjadi peningkatan harapan sebesar 1\% maka kualitas hidup tenaga kerja penyandang disabilitas akan naik sebesar $0.686 \%$. Responden masih memiliki citacita atau target yang ingin dicapai seperti melakukan kegiatan insiatif mengantar teman-teman pengguna kursi roda untuk kontrol kesehatan sebagai bentuk solidaritas agar teman-teman penyandang disabilitas pengguna kursi roda agar tidak terkena dampak dari Ulkus Dekubitus yaitu penyakit yang diakibatkan oleh tekanan yang terus dibebankan pada tubuh bagian bawah, yang jika dibiarkan dapat berakibat fatal.

Variabel dukungan sosial berpengaruh positif terhadap kualitas hidup tenaga kerja penyandang disabilitas dengan koefisien sebesar 0.626. Hal ini menunjukkan bahwa setiap terjadi peningkatan dukungan sosial sebesar 1\% maka kualitas hidup tenaga kerja penyandang disabilitas akan naik sebesar $0.626 \%$. Berdasarkan fakta di Kabupaten Bantul, akses dan penerimaan masyarakat terhadap penyandang disabilitas secara kasat mata sudah terlihat lebih menonjol disbanding daerah lain. Terlihat dari banyaknya jumlah motor roda tiga yang beredar sebagai kendaraan untuk penyandang disabilitas daksa, adanya yayasan yang memberi pelatihan atau pekerjaan kepada penyandang disabilitas, hingga komunitas-komunitas penyandang disabilitas yang aktif untuk saling membantu anggotanya. Hal ini juga yang 
menjadi pemicu semangat bagi tenaga kerja penyandang disabilitas untuk tetap memiliki kehidupan yang produktif sebagaimana masyarakat pada umumnya.

Variabel religiusitas berpengaruh positif terhadap kualitas hidup tenaga kerja penyandang disabilitas dengan koefisien sebesar 0.616. Hal ini menunjukkan bahwa setiap terjadi peningkatan religiusitas sebesar 1\% maka kualitas hidup tenaga kerja penyandang disabilitas akan naik sebesar $0.616 \%$. Temuan ini menunjukkan bahwa semakin religius seseorang maka kualitas hidup seseorang akan mengalami peningkatan. Hal ini menjadi rasional, karena dalam nilai-nilai agama terdapat perintah untuk optimis, percaya dengan bantuan Allah, dan menggantungkan harapan pada Allah SWT yang memiliki kekuasaan atas segala hal. Berikut merupakan ayat-ayat Al-Qur'an dan hadis yang menanamkan nilai-nilai optimisme, harapan, maupun perasaan terdukung sehingga dapat meningkatkan kualitas hidup.

"Maka Kami telah memperkenankan doanya dan menyelamatkannya dari pada kedukaan. Dan demikianlah Kami selamatkan orang-orang yang beriman" (Al-Anbiya: 88).

"Dari Abu Hurairah RA berkata, Rasulullah SAW bersabda, Allah berfirman : Aku tergantung persangkaan hambaKu pada diriKu, dan Aku bersamanya apabila ia mengingatKu" (HR. Bukhari).

Fakta yang ditemukan di lapangan menunjukkan nilai-nilai tersebut tertanam pada masyarakat Bantul sehingga kebanyakan dari korban gempa tetap menggunakan sudut pandang legawa meskipun kondisi fisik yang memiliki keterbatasan tidak seperti orang-orang pada umumnya. Tanpa perasaan optimisme, harapan, dukungan sosial, dan religiusitas bukan tidak mungkin banyak korban gempa yang memutuskan untuk mengakhiri hidupnya. Salah satu responden secara berterus terang mengaku sempat berpikir untuk bunuh diri akibat kondisi disabilitas yang diperolehnya.
Namun demikian dengan adanya nilai-nilai agama dalam diri responden tersebut maka muncul penilaian bahwa apa yang Allah berikan adalah yang terbaik bagi kehidupannya. Berdasarkan fakta tersebut, maka pengaruh nilai-nilai agama tidak dapat diabaikan.

\section{KESIMPULAN DAN IMPLIKASI}

Tenaga kerja penyandang disabilitas di Bantul memiliki rata-rata nilai kualitas hidup sebesar 71.18. Nilai tersebut merupakan kombinasi skor kualitas hidup objektif dan subjektif. Rata-rata skor kualitas hidup subjektif yang diperoleh lebih besar dibandingkan rata-rata skor kualitas hidup objektif. Hal ini menunjukkan bahwa responden memiliki rasa kepuasan dan kepentingan yang lebih tinggi walaupun objek yang telah dimiliki tergolong tidak bernilai begitu besar.

Nilai kualitas hidup objektif menunjukkan bahwa mayoritas responden telah memilki rumah pribadi, memiliki pendapatan bulanan Rp 500,000-Rp 1,000,000, dan terkadang memiliki keluhan kesehatan akibat kondisi disabilitas. Selain itu, waktu yang dihabiskan tiap minggunya oleh mayoritas responden untuk bekerja dan melakukan pekerjaan adalah 31 hingga 40 jam lebih. Adapun untuk pelatihan, mayoritas tenaga kerja penyandang disabilitas tidak menggunakan waktunya sama sekali karena belum tersedianya pelatihan rutin bagi penyandang disabilitas.

Mayoritas responden hampir selalu merasa dipedulikan oleh masyarakat sekitar, hampir tidak pernah merasa cemas berlebihan, hampir selalu terlibat pada masyarakat, dan hampir selalu mampu menahan emosi diri.

Kualitas hidup subjektif menunjukkan bahwa kondisi kesehatan dan hubungan keluarga dianggap paling penting oleh mayoritas responden. Adapun untuk skala kepuasan, hubungan dengan keluarga dan masyarakat dianggap paling memuaskan oleh mayoritas responden. 
Faktor-faktor yang mempengaruhi kualitas hidup tenaga kerja penyandang disabilitas di Bantul adalah pendapatan, optimisme, harapan, dukungan sosial, dan religiusitas. Seluruh faktor berpengaruh secara positif. Pendapatan memberi pengaruh paling besar dengan koefisien sebesar 8.738. Namun pendapatan yang diperoleh oleh kebanyakan tenaga kerja penyandang disabilitas ternyata masih berada di bawah UMR. Hal ini perlu menjadi perhatian karena walaupun Undang-undang dan Perda tentang ketenagakerjaan mengatur lembaga pemerintahan maupun swasta untuk telah memberi kesempatan kerja bagi penyandang disabilitas, namun kenyataannya sektor yang menyerap tenaga kerja penyandang disabilitas di Kabupaten Bantul masih didominasi oleh sektor informal yang belum memungkinkan untuk memberikan pendapatan tetap di atas UMR. Hal ini menunjukkan bahwa masih besar kemungkinan untuk tenaga kerja penyandang disabilitas hidup di bawah garis kemiskinan.

\section{DAFTAR PUSTAKA}

Agung I Gusti Ngurah, 2005. Manajemen Penulisan Skripsi, Tesis, dan Disertasi: Kiat-kiat untuk Mempersingkat Waktu Penulisan Karya Ilmiah yang Bermutu. Jakarta : Rajawali Press.

Ariefanto Moch. Doddy, 2012. Ekonometrika: Esensi dan Aplikasi dengan Menggunakan Eviews. Jakarta : Erlangga.

[BPS] Badan Pusat Statistik Kabupaten Bantul, 2016. Kabupaten Bantul dalam Angka 2016. Jogjakarta: BPS.

Cummins, Robert A, 1997. Comprehensive Quality of Life Scale for Disability. Suburban: Daekin University.

Greene, William H, 2012. Econometric Analysis. New York : Pearson.

[Kemenkes] Kementerian Kesehatan, 2014. Buletin Situasi Penyandang Disabilitas. Jakarta : Kemenkes
Lakey Brian dan Cohen Sheldon, 2000. Social Support Theory and Measurement. Di dalam: Cohen Sheldon, Underwood Lynn G, Gotlieb Benjamin H, editor. Social Support Measurement and Intervention: A Guide for Heakth and Social Scientists. 2002. New York, United Kingdom. NewYork : Oxford Press. Hlm 29-52.

Lind, Marchal, Wathen, 2007. Teknikteknik Statistika dalam Bisnis dan Ekonomi Menggunakan Kelompok Data Global. Sungkono, penerjemah; Citra Shelvy, editor. Jakarta : Penerbit Salemba Empat. Terjemahan dari: Statistical Techniques in Business and Economics with Global Data Sets. Ed ke13.

Nofitri N F M, 2009. Gambaran Kualitas Hidup Penduduk Dewasa pada Lima Wilayah di Jakarta [Skripsi]. Depok : Universitas Indonesia.

Peraturan Daerah Provinsi Daerah Istimewa Yogyakarta No. 4 Tahun 2012, tentang Perlindungan dan Pemenuhan Hak-hak Penyandang Disabilitas.

Peraturan Daerah Kabupaten Bantul No. 11 Tahun 2015, tentang Pemenuhan Hakhak Tenaga Kerja Penyandang Disabilitas.

Prasetyo dan Jannah, 2010. Metode Penelitian Kuantitatif: Teori dan Aplikasi. Jakarta : Rajawali Press.

Sangadji dan Sopiah, 2010. Metodologi Penelitian: Pendekatan Praktis dalam Penelitian. Yogyakarta : Penerbit Andi.

Sarwoko, 2005. Dasar-dasar Ekonometrika. Yogyakarta : Penerbit Andi.

Seligman Martin, 2006. Learned Optimism. New York : Vintage Books.

Sugiyono. 2011. Metode Penelitian Kuantitatif dan Kualitatif. Bandung : Alfabeta.

Suliyanto. 2011. Ekonometrika Terapan: Teori dan Aplikasi dengan SPSS. Yogyakarta : Penerbit Andi.

Syafi'ie M. 2014. Pemenuhan Aksesibilitas pada Penyandang Disabilitas. Jurnal Inklusi. 1(2): 269-308. 
Snyder C R, Rand Kevin L, Sigmon David S. 2002.Hope Theory: A Member of the Positive Psychology Family. Di dalam: Snyder C R, Lopez Shane J, editor. Handbook of Positive Psychology; 2002; New York, United Kingdom. New York : Oxford Press. Hlm 257-276.
Undang-undang Republik Indonesia No. 8 Tahun 2016, tentang Penyandang Disabilitas.

Widarjono, Agus. 2016. Ekonometrika: Pengantar dan Aplikasinya. Yogyakarta : STIM YKPN 